\title{
PENGARUH MODEL TEAM GAMES TURNAMEN DAN GRUP INVESTIGASI SERTA PENGETAHUAN AWAL SISWA TERHADAP KEMAMPUAN MEMBACA PEMAHAMAN
}

\author{
Sigit Vebrianto Susilo ${ }^{1}$ ) \\ sigit_vebrianto@yahoo.com
}

\begin{abstract}
Abstrak
Penelitian ini bertujuan untuk mengetahui pengaruh model pembelajaran dan pengetahuan awal siswa terhadap kemampuan membaca pemahaman. Penelitian ini dilakukan pada siswa kelas V SD Negeri 1 Munjul Kecamatan Majalengka Kabupaten Majalengka pada tahun 2016 dengan 60 sampel. Pengambilan data diperoleh melalui tes analisis Varian (ANAVA) dua jalur dengan desain treatmeant by level $2 \times 2$. Hasil penelitian menunjukkan bahwa: (1) Hasil kemampuan membaca pemahaman siswa yang menggunakan model team games turnamen lebih baik dari pada siswa yang menggunakan model grup investigation. (2) Terdapat pengaruh interaksi antara model pembelajaran dengan pengetahuan awal siswa terhadap kemampuan membaca pemahaman. (3) Hasil kemampuan membaca pemahaman siswa yang pengetahuan awal tinggi dan belajar dengan model team games turnamen lebih baik dari pada model grup investigation, (4) Hasil kemampuan membaca pemahaman siswa yang pengetahuan awal rendah dan belajar dengan model team games turnamen lebih baik dari pada model grup investigation,
\end{abstract}

Kata Kunci: Model pembelajaran team games turnamen, model pembelajaran grup investigasi, pengetahuan awal, kemampuan, membaca pemahaman.

\footnotetext{
${ }^{1}$ Penulis adalah dosen tetap Prodi PGSD Fakultas Pendidikan Dasar dan Menengah Universitas Majalengka
} 


\section{Pendahuluan}

Membaca pemahaman adalah merupakan salah satu kemampuan yang memang harus dikembangkan dalam upaya meningkatkan pengetahuan siswa akan ilmu dan informasi yang senantiasa berkembang. Sejak tahun 2000 kemampuan membaca pemahaman merupakan salah satu kompetensi yang sudah dijadikan sebagai kemampuan yang dimiliki oleh siswa dati tingkat dasar (SD) hingga menengah pertama (SMP). Dari data survei Progress In International Reading Literacy Study (PIRLS) yang dilaksanakan pada tahun 2011 rerata siswa kelas IV sekolah dasar di Indonesia memperoleh skor 405 per 1000, sehingga dapat dikategorikan memiliki kompetensi "rendah" (400-474), (Abidin: 2013).

Lebih lanjut Abidin (2013) juga menyebutkan sebagai bahan perbandingan lebih dari 95\% siswa di Indonesia hanya mencapai level menengah, sementara lebih dari $50 \%$ siswa Taiwan mampu mencapai level tinggi dan advance. Dengan demikian merujuk kepada pernyataan bahwa manusia diciptakan dengan segala kesempurnaan dan memiliki kemampuan yang sama, demikian dapat disimpulkan bahwa proses pengajaran yang di terapkan di Indonesia tidak sama atau berbeda dengan yang telah di tetapkan atau di standarkan (dalam pengujiannya) oleh Internasional.

Berbagai temuan di kelas mengungkapkan bahwa pembelajaran Bahasa dan Sastra Indonesia di sekolah dasar belum berlangsung seperti yang diharapkan. Guru cenderung menggunakan teknik pembelajaran yang bercorak teoretis dan hafalan sehingga kegiatan pembelajaran berlangsung kaku, monoton, dan membosankan. Berbagai alasan yang di ungkapkan tadi bukan tanpa alasan karena pada penilaian kemampuan membaca pemahaman yang dilakukan oleh Programme for International Student Assessment (PISA) menunjukan bahwa Indonesia merupakan negara yang memiliki tingkat kemampuan membaca rendah. Berdasarkan penilaian PISA pada tahun 2000 bahwa Indonesia mempunyai skor 371 sehingga menempatkan Indonesia memiliki peringkat terendah ketiga dengan negara yang memiliki tingkat kemampuan membaca pemahaman rendah (OECD. 2013: 76).

Berdasarkan hasil studi pendahuluan yang dilakukan pada Februari-April 2016 di SDN Kulur II Kecamatan Majalengka Kabupaten Majalengka, beberapa fenomena yang muncul dapat dijadikan sebagai kondisi empiris. Studi pendahuluan dilakukan melalui penilaian kemampuan membaca di SDN Kulur II sehingga memperoleh data awal kemampuan membaca siswa, dan dari hasil tersebut dapat disimpulkan bahwa kemampuan membaca pemahaman siswa masih masuk dalam kategori rendah karena dibuktikan dengan hasil belajar nya masih di bawah kriteria ketuntasan minimal (KKM). Kemudian berdasarkan hasil observasi, dapat dikemukakan bahwa memang proses pembelajaran tidak dikemas sedemikian rupa sehingga berjalan tidak menarik. Siswa kurang diarahkan ke dalam tahap penyerapan dan pemahaman isi bacaan secara mendalam sehingga terkesan siswa hanya melafalkan bacaan. Lebih lanjut, proses pembelajaran hanya diarahkan untuk menjawab pertanyaan yang di lontarkan oleh guru kemudian siswa mencari jawaban dalam bacaan secara berulang-ulang sehingga siswa mampu menjawab pertanyaan dalam bacaan. Dengan demikian kompetensi yang di standarkan oleh guru hanya siswa mampu membaca dengan nyaring, dengan baik, dapat menjawab pertanyaanpertanyaan dengan benar, maka setelah itu selesailah tugas guru.

Berdasarkan data-data empiris yang dikemukakan di atas, perlu dilakukan sebuah perubahan besar dalam proses pelaksanaan pembelajaran khususnya dalam pembelajaran membaca pemahaman. Berbagai upaya yang 
seyogyanya dilakukan dalam tujuan untuk membenahi pembelajaran yang bermuara pada peningkatan kualitas mutu guna meningkatkan pula pencapaian kompetensi siswa. Pembelajaran membaca pemahaman sejatinya siswa diarahkan untuk tidak sekedar membaca dan mengandalkan bacaan yang sudah ada, kemudian tidak hanya pula ketika siswa dapat menjawab pertanyaan dari guru kemudian selesai. Di sisi lain guru harus mampu menumbuhkan pemikiran kritis dan kreatif dalam kegiatan membaca pemahaman sehingga timbul sebuah pemahaman dari bacaan dan guru dapat mengeksplorasi setiap bahan bacaan tersebut tidak hanya bahan bacaan yang sudah ada.

\section{Kajian Teoritik}

Membaca adalah kegiatan proses manusia menemukan sesuatu hal baru sebagai bentuk informasi baik mengenai ilmu pengetahuan, teknologi ataupun masalah sosial. Cline et.al (2006: 2) mengemukakakan reading is decoding and understanding written texts. Decoding requires translating the symbols of writing system (including Braille) into the spoken words which they represent. Understanding is determined by the purposes for reading, the context, the nature of the text, and the readers' strategies and knowledge. Lebih lanjut Cline et.al (2006: 2) juga menyatakan bahwa reading is the process of deriving meaning from the text. For the majority of readers, this process involves decoding written text. Some individuals require adaptation such as Braille or auditorization to support the decoding process. Understanding is determined by the purposes for reading, the context, the nature of the text, and the reader's strategies and knowledge. Tarigan (2008) menyatakan membaca pemahaman (reading for undersanding) adalah jenis membaca untuk memahami standarstandar atau norma kesastraan, resensi kritis, drama tulis, dan pola-pola fiksi dalam usaha memperoleh pemahaman terhadap teks, pembaca menggunakan strategi tertentu. Pemilihan strategi berkaitan erat dengan faktor-faktor yang terlibat dalam pemahaman, yaitu pembaca teks dan konteks. Westwood (2008) stated that reading comprehension is often conceptualised as functioning at different levels of sophistication and referred to, for example, as literal, inferential and critical. The most basic level (literal) is where the reader is able to understand the factual information presented in a passage of text - for example, he or she can tell you the name of the main character and what he does for a living, because that information is stated explicitly in the text. Membaca pemahaman merupakan kegiatan memahami isi bacaan yang dibacanya. Somadayo (2011) mengatakan bahwa membaca pemahaman merupakan suatu proses pemerolehan makna yang secara aktif melibatkan pengetahuan dan pengalaman yang telah dimiliki oleh pembaca serta dihubungkan dengan isi bacaan. Adapun menurut Andayani (2009) membaca pemahaman atau komprehensi ialah kemampuan membaca untuk mengerti ide pokok, detail penting, dan seluruh pengertian. Ditambahkan oleh Fanany (2012) membaca pemahaman yaitu membaca yang penekanannya diarahkan pada keterampilan memahami dan menguasai isi bacaan. Jhonson mendefinisikan "Reading is the practice of using text to create meaning". Membaca adalah sebuah kegiatan praktik dengan menggunakan bacaan-bacaan untuk menemukan makna yang terdapat di dalamnya.

Dengan demikian membaca pemahaman merupakan suatu proses pemerolehan makna yang melibatkan aktif pengalaman dan pengetahuan, menguasai isi bacaan dan memahami detail bacaan yang dibacanya. Maka dari itu dalam proses kegiatan membaca perlu diarahkan untuk benar-benar melibatkan siswa secara aktif agar memperoleh pemahaman secara 
menyeluruh. Keterlibatan siswa secara aktif disini dimaksudkan agar siswa dapat membangun sendiri pengetahuannya sehingga proses membaca pemahaman dapat terlaksana secara efektif dan efisien. Lebih lanjut Abidin (2012) menjelaskan bahwa prosedur pembelajaran membaca pemahaman adalah (1) Tahap Prabaca, (2) Tahap Membaca, (3) Tahap Pascabaca. Sejalan dengan prosedur pembelajaran membaca pemahaman, kembali Abidin (2016: 5) menjelakan bahwa pembelajaran membaca setidaknya mempunyai tiga tujuan. Ketiga tujuan utama tersebut adalah (1) memungkinkan siswa agar mampu menikmati kegiatan membaca, (2) mampu membaca dalam hati dengan kecepatan baca yang fleksibel, (3) serta memperoleh tingkat pemahaman yang cukup atas isi bacaan. Selanjutnya Abidin (2010: 5) secara lebih rinci memaparkan tujuan pertama, pembelajaran membaca haruslah ditekankan pada upaya mendukung siswa agar ia mampu menikmati kegiatan baca yang dilakukannya. Hal ini sangat penting mengingat kenikmatan membaca adalah dasar bagi kegiatan membaca. Tanpa rasa nikmat yang dirasakan siswa, pembelajaran membaca bisa saja tidak mampu mencapai tujuan yang diharapkan. Dengan demikian, langkah awal pembelajaran membaca harus ditujukan agar anak termotivasi membaca sehingga ia bisa menjadikan membaca sebagai kegiatan yang menyenangkan.Tujuan pertama pembelajaran membaca secara lebih luas dapat ditafsirkan agar siswa mencintai membaca. Tujuan ini menjadi sangat penting sebab mencitai membaca adalah modal awal agar siswa bisa membaca sekaligus tetap menjadi pembaca.

Model team games turnamen merupakan pengembangan model pembelajaran kooperatif yang digagas Slavin. Menurut Slavin (2005) model pembelajaran kooperatif merupakan suatu model pembelajaran yang mengutamakan adanya kelompok-kelompok. Setiap siswa yang ada dalam kelompok mempunyai tingkat kemampuan yang berbeda-beda (tinggi, sedang dan rendah) dan jika memungkinkan anggota kelompok berasal dari ras, budaya, suku yang berbeda serta memperhatikan kesetaraan gender. Model pembelajaran kooperatif mengutamakan kerja sama dalam menyelesaikan permasalahan untuk menerapkan pengetahuan dan keterampilan dalam rangka mencapai tujuan pembelajaran. Semua model pembelajaran ditandai dengan adanya struktur tugas, struktur tujuan dan struktur penghargaan. Struktur tugas, struktur tujuan dan struktur penghargaan pada model pembelajaran kooperatif berbeda dengan struktur tugas, struktur tujuan serta struktur penghargaan model pembelajaran yang lain. Dalam proses pembelajaran dengan model pembelajaran kooperatif, siswa didorong untuk bekerja sama pada suatu tugas bersama dan mereka harus mengoordinasikan usahanya untuk menyelesaikan tugas yang diberikan guru.

Teams Games Tournament (TGT), pada mulanya dikembangkan oleh David Devries dan Keith Edwards, ini merupakan metode pembelajaran pertama dari Johns Hopkins. Dalam metode ini, para siswa dibagi dalam tim belajar yang terdiri atas empat sampai lima orang yang berbeda-beda tingkat kemampuan, jenis kelamin, dan latar belakang etniknya. Guru menyampaikan pelajaran, lalu siswa bekerja dalam tim mereka untuk memastikan bahwa semua anggota tim telah menguasai pelajaran. Selanjutnya diadakan turnamen, di mana siswa memainkan game akademik dengan anggota tim lain untuk menyumbangkan poin bagi skor timnya. TGT menambahkan dimensi kegembiraan yang diperoleh dari penggunaan permainan. Teman satu tim akan saling membantu dalam mempersiapkan diri untuk permainan dengan mempelajari lembar kegiatan dan menjelaskan masalah- 
masalah satu sama lain, memastikan telah terjadi tanggung jawab individual ( Slavin, 2008:16-20). Menurut Trianto (2011:83), Teams Games Tournament merupakan salah satu teknik pembelajaran dalam model pembelajaran kooperati (cooperatif learning). Teknik ini dikembangkan pertama kali oleh David de Vries dan Keath Edward pada tahun 1995. Pada model ini siswa memainkan permainan dengan anggota-anggota tim lain untuk memperoleh tambahan poin untuk skor tim mereka. Model pembelajaran kooperatif yang satu ini memiliki tujuan untuk melatih siswa agar dapat bekerja sama sekaligus memiliki rasa kompetitif yang positif. Kerja sama di sini akan tampak dalam kelompok kecil mereka, sedangkan kompetisinya akan trelihat dalam kelompok besar yaitu ketika mereka berkompetisi dengan kelompok lain. Model pembelajaran Teams Games Tournament (TGT) adalah salah satu tipe atau model pembelajaran kooperatif yang mudah diterapkan, melibatkan aktivitas seluruh siswa tanpa harus ada perbedaan status, melibatkan peran siswa sebagai tutor sebaya dan mengandung unsur permainan dan reinforcement. Menurut Slavin (2008:25), pembelajaran kooperatif tipe TGT terdiri dari 5 komponen utama, yaitu presentasi di kelas, tim (kelompok), game (permainan), turnamen (pertandingan), dan perhargaan kelompok. Prosedur pelaksanaan TGT dimulai dari aktivitas guru dalam menyampaikan pelajaran, kemudian siswa bekerja dalam tim mereka untuk memastikan bahwa semua anggota tim telah menguasai pelajaran. Selanjutnya diadakan turnamen, di mana siswa memainkan game akademik dengan anggota tim lain untuk menyumbangkan poin bagi skor timnya.

Lebih lanjut Slavin (2008:26-28) menjelaskan mengenai langkah-langkah pembelajaran TGT terdiri dari siklus reguler dari aktivitas pengajaran sebagai berikut:

\section{Presentasi Kelas}

Pada awal pembelajaran guru menyampaikan materi dalam penyajian kelas, biasanya dilakukan dengan pengajaran langsung atau dengan ceramah, dan diskusi yang dipimpin guru.

2. Belajar Kelompok (Tim)

Guru membagi siswa dalam kelompok-kelompok kecil. Siswa bekerja dalam kelompok yang terdiri atas 5 orang yang anggotanya heterogen dilihat dari kemampuan akademik, jenis kelamin, dan ras atau etnik yang berbeda. Dengan adanya heterogenitas anggota kelompok, diharapkan dapat memotivasi siswa untuk saling membantu antar siswa yang berkemampuan lebih dengan siswa yang berkemampuan kurang dalam menguasai materi pelajaran. Hal ini akan menyebabkan tumbuhnya rasa kesadaran pada diri siswa bahwa belajar secara kooperatif sangat menyenangkan.

Pada saat pembelajaran, fungsi kelompok adalah untuk lebih mendalami materi bersama teman kelompoknya dan lebih khusus untuk mempersiapkan anggota kelompok agar bekerja dengan baik dan optimal pada saat game/tournamen. Setelah guru menginformasikan materi dan tujuan pembelajaran, kelompok berdiskusi dengan menggunakan modul. Dalam kelompok terjadi diskusi untuk memecahkan masalah bersama, saling memberikan jawaban dan mengoreksi jika ada anggota kelompok yang salah dalam menjawab. Penataan ruang kelas diatur sedemikianrupa sehingga proses pembelajaran dapat berlangsung dengan baik.

3. Persiapan Permainan/Pertandingan

Guru mempersiapkan pertanyaan pertanyaan yang berhubungan dengan materi, bernomor 1 sampai 30. Kemudian guru mempersiapkan alat-alat untuk permainan, yaitu: kartu permainan yang dilengkapi nomor, skor, pertanyaan, dan jawaban mengenai materi. 


\section{Permainan/Pertandingan}

(Game/Tournamen)

Game/Tournamen terdiri dari pertanyaan-pertanyaan yang dirancang untuk menguji pengetahuan yang diperoleh siswa dari penyajian kelas dan belajar kelompok. Tiap kelompok (tim) mendapat kesempatan untuk memilih kartu bernomor yang tersedia pada meja turnamen dan mencoba menjawab pertanyaan yang muncul. Apabila tiap anggota dalam suatu tim tidak bisa menjawab pertanyaannya, maka pertanyaan tersebut dilempar kepada kelompok lain, searah jarum jam. Tim yang bisa menjawab dengan benar pertanyaan itu akan mendapat skor yang telah tertera dibalik kartu tersebut. Skor ini yang nantinya dikumpulkan tim untuk menentukan skor akhir tim. Pemilihan kartu bernomor akan digilir pada tiap-tiap tim secara bergantian searah jarum jam, sampai habis jatah nomornya.

5. Penghargaan Tim

Penghargaan diberikan kepada tim yang menang atau mendapat skor tertinggi, skor tersebut pada akhirnya akan dijadikan sebagai tambahan nilai tugas siswa. Selain itu diberikan pula hadiah (reward) sebagai motivasi belajar.

$$
\text { Riset tentang keunggulan }
$$

pembelajaran kooperatif tipe Teams Games Tournament (TGT) dalam pembelajaran telah banyak dilakukan oleh pakar pembelajaran maupun oleh para guru di sekolah. Dari tinjuan psikologis, terdapat dasar teoritis yang kuat untuk memprediksi bahwa metode - metode pembelajaran kooperatif tipe Teams Games Tournament (TGT) yang menggunakan tujuan kelompok dan tanggung jawab individual akan meningkatkan pencapaian prestasi siswa. Dua teori utama yang mendukung pembelajaran kooperatif tipe Teams Games Tournament (TGT) adalah teori motivasi dan teori kognitif. \begin{tabular}{lllr}
\multicolumn{2}{c}{ Aktivitas } & belajar & dengan \\
permainan yang & dirancang & dalam \\
pembelajaran & kooperatif model & Teams
\end{tabular} Games Tournament (TGT) memungkinkan siswa dapat belajar lebih rileks disamping menumbuhkan tanggung jawab, kejujuran, kerja sama, persaingan sehat dan keterlibatan belajar.

Pembelajaran kooperatif tipe GI didasari oleh gagasan John Dewey tentang pendidikan yang menyimpulkan bahwa kelas merupakan cermin masyarakat dan berfungsi sebagai laboratorium untuk belajar tentang kehidupan di dunia nyata yang bertujuan mengkaji masalah-masalah sosial dan antar pribadi. Model pembelajaran kooperatif ini berasal dari jamannya Dewey, kemudian diperbaharui dan diteliti pada beberapa tahun terakhir oleh Shlomo dan Yael Sharan, serta Rachel-Lazarowitz di Israel (Slavin, 2005). Pada dasarnya model ini dirancang untuk membimbing para siswa mendefinisikan masalah, mengeksplorasi berbagai hal mengenai masalah itu, mengumpulkan data yang relevan, mengembangkan dan menguji hipotesis. Ibrahim, dkk. (2000: 23) menyatakan "dalam kooperatif tipe GI guru membagi kelas menjadi kelompok-kelompok dengan anggota 5 atau 6 siswa heterogen dengan mempertimbangkan keakraban dan minat yang sama dalam topik tertentu. Siswa memilih sendiri topik yang akan dipelajari, dan kelompok merumuskan penyelidikan dan menyepakati pembagian kerja untuk menangani konsep-konsep penyelidikan yang telah dirumuskan. Dalam diskusi kelas ini diutamakan keterlibatan pertukaran pemikiran para siswa."

Metode investigasi kelompok sering dipandang sebagai metode yang paling kompleks dan paling sulit untuk dilaksanakan dalam pembelajaran kooperatif. Metode ini melibatkan siswa sejak perencanaan, baik dalam menentukan topik maupun cara untuk mempelajarinya melalui investigasi. Metode ini menuntut para siswa untuk 
memiliki kemampuan yang baik dalam berkomunikasi maupun dalam ketrampilan proses kelompok (group process skills). Para guru yang menggunakan metode investigasi kelompok umumnya membagi kelas menjadi beberapa kelompok yang beranggotakan 5 hingga 6 siswa dengan karakteristik yang heterogen. Pembagian kelompok dapat juga didasarkan atas kesenangan berteman atau kesamaan minat terhadap suatu topik tertentu. Para siswa memilih topik yang ingin dipelajari, mengikuti investigasi mendalam terhadap berbagai subtopik yang telah dipilih, kemudian menyiapkan dan menyajikan suatu laporan di depan kelas secara keseluruhan. Menurut Sharan and Sharan (Slavin 2005: 24) "Group Investigation merupakan perencanan pengaturan kelas yang umum di mana para siswa bekerja sama dalam kelompok kecil menggunakan pertanyaan kooperatif, diskusi kelompok, serta perencanaan dan proyek kooperatif"'.

Dalam model Group

Investigation terdapat tiga konsep utama, yaitu: penelitian atau enquiri, pengetahuan atau knowledge, dan dinamika kelompok atau the dynamic of the learning group, (Winaputra, 2001:75). Penelitian di sini adalah proses dinamika siswa memberikan respon terhadap masalah dan memecahkan masalah tersebut. Pengetahuan adalah pengalaman belajar yang diperoleh siswa baik secara langsung maupun tidak langsung. Sedangkan dinamika kelompok menunjukkan suasana yang menggambarkan sekelompok saling berinteraksi yang melibatkan berbagai ide dan pendapat serta saling bertukar pengalaman melaui proses saling beragumentasi.

Menurut Sharan and Sharan (Slavin 2005: 24) "Group Investigation merupakan perencanan pengaturan kelas yang umum di mana para siswa bekerja sama dalam kelompok kecil menggunakan pertanyaan kooperatif, diskusi kelompok, serta perencanaan dan proyek kooperatif'.
Dalam model ini siswa dibebaskan untuk membentuk kelompoknya sendiri yang terdiri dari dua sampai enam orang anggota, yang kemudian memilih topiktopik yang akan dipelajari seta membahasanya sampai akhirnya menyimpulkan hasil pembahasan tersebut. Group Investigation diimplementasikan melalui tahapan-tahapan tertentu. Tahapan-tahapan Group Investigation dikembangkan oleh beberapa ahli diantaranya oleh Robert Slavin, Shlomo dan Yael Sharan, serta Bruce Joyce dan koleganya. Menurut Slavin (2005: 218) dalam Group Investigation para murid bekerja melalui enam tahap yaitu:

1. Mengidentifikasikan topik dan mengatur murid ke dalam kelompok

2. Merencanakan tugas yang akan dipelajari

3. Melaksanakan investigasi

4. Menyiapkan laporan akhir

5. Mempresentasikan laporan akhir

6. Evaluasi

Slavin (2005: 215) mengatakan bahwa:

"Group investigation tidak dapat diimplementasikan dalam lingkungan pendidikan yang tidak mendukung dialog interpersonal atau yang tidak memperhatikan dimensi rasa sosial dari pembelajaran di dalam kelas". Bertemali dengan pendapat diatas, maka sudah seharusnya guru dapat membuat kelas menjadi nyaman melalui rancangan sntem pembelajaran yang menarik dan menyenangkan. Menurut Dewey (Arends, 2007), kelas seharusnya mencerminkan masyarakat yang lebih luas dan menjadi laboratorium bagi pembelajaran kehidupan nyata. Dewey (Slavin, 2005) juga mengungkapkan bahwa kelas adalah sebuah tempat kreatifitas kooperatif bagi guru dan siswa untuk membangun proses pembelajaran, didasarkan pada perencanaan mutual dari berbagai pengalaman, kapasitas, dan kebutuhan mereka masing-masing. 


\section{Metode Penelitian}

Penelitian ini merupakan penelitian dengan menggunakan eksperimen dengan desain treatment by level $2 \times 2$. Pada eksperimen ini peneliti menggunakan dua model pembelajaran yaitu model team games turnamen dan model GI. Subjek penelitian dibagi kedalam dua kelas yaitu kelas ekperimen satu dengan pembelajaran menggunakan model team games turnamen dan kelas eksperimen dua dengan pembelajaran menggunakan model GI, sedangkan variabel atribut diklasifikasin kedalam kategori pengetahuan awal tinggi dan rendah. Jumlah keseluruhan siswa yang menjadi subjek penelitian adalah 60 orang siswa yang dibagi kedalam dua kelas diantaranya kelas A sebanyak 30 Orang dan kelas B sebanyak 30 orang.

\section{Tabel 1}

\section{Jumlah Anggota Sel Berdasarkan Model Pembelajaran \\ dan kelompok Pengetahuan Awal}

Teknik analisis data yang digunakan dalam penelitian ini adalah teknik analisis varian (ANAVA) dua jalur. Teknik ini dipilih atas dasar tujuan peneliti untuk mengetahui perbedaan hasil kemampuan membaca pemahaman berdasarkan pada kelas pembelajaran (model pembelajaran), perbedaan hasil kemampuan membaca pemahaman berdasarkan tingkatan pengetahuan awal (tinggi dan rendah) dan kelas pembelajaran, serta guna mengetahui mengenai interaksi antara model pembelajaran dan pengetahuan awal terhadap kemampuan membaca pemahaman.

\section{A. Hasil penelitian dan Pembahasan}

Hasil analisis dan deskripsi, peneliti melihat adanya perbedaan hasil kemampuan kemampuan membaca pemahamanantara siswa yang pembelajarannya menggunakan model team games turnamen dengan siswa yang pembelajarannya menggunakan model

group investigation. skor rata-rata pada tahap post tes kemampuan membaca pemahaman siswa untuk kelas TGT ada 44.9333 dengan standar deviasi 2.82761 . Kemudian terlihat juga bahwa skor maksimum adalah 49 dan skor minimum 40 dengan median 45.0000. Skor rata-rata tersebut lebih tinggi dibandingkan dengan siswa yang pembelajarannya menggunakan model GI, yaitu 38.9667 dan standar deviasi 6.30681. Kemudian untuk nilai maksimum 48 dan nilai minimum 30 dengan median 39.0000.

$\begin{array}{ccc}\text { Selain } & \begin{array}{c}\text { melihat } \\ \text { kemampuan } \\ \text { membaca }\end{array} & \begin{array}{r}\text { kemampuan } \\ \text { pemahaman } \\ \text { pembelajaran, }\end{array}\end{array}$ selanjutnya peneliti melihat kemampuan kemampuan membaca pemahaman berdasarkan pengetahuan awal dan kelas pembelajaran. Hal ini bertujuan guna melihat sejauh mana pengaruh antara kelas pembelajaran dan pengetahuan awal terhadap kemampuan membaca pemahaman. rata-rata hasil kemampuan kemampuan membaca pemahaman berdasarkan kelas pembelajaran dan pengetahuan awal dapat dideskripsikan bahwa skor rata-rata hasil kemampuan kemampuan membaca pemahaman untuk siswa yang memiliki pengetahuan awal tinggi dan belajar dengan menggunakan model TGT yaitu 49.3750, standar deviasi 0.91613, skor maksimum untuk siswa yang memiliki pengetahuan awal tinggi dan belajar dengan menggunakan model TGT yaitu 50,00; minimum 48,00 dengan

\begin{tabular}{|c|l|l|}
\hline MP(A) & $\begin{array}{l}\text { Model } \\
\text { Pembelajaran } \\
\text { Team games } \\
\text { turnamen } \\
\left(\mathrm{A}_{1}\right)\end{array}$ & $\begin{array}{l}\text { Model } \\
\text { Pembelajaran } \\
\text { Group } \\
\text { Investigation } \\
\left(\mathbf{A}_{2}\right)\end{array}$ \\
\hline Tinggi $\left(\mathrm{B}_{1}\right)$ & 8 & 8 \\
\hline Rendah $\left(\mathbf{B}_{2}\right)$ & 8 & \\
\hline
\end{tabular}


median 47.00. Skor rata-rata tersebut lebih tinggi dibandingkan dengan kelompok siswa yang memiliki

Test Statisticsa

\begin{tabular}{|l|r|}
\hline & PosTes \\
\hline Mann-Whitney U & 188.500 \\
Wilcoxon W & 653.500 \\
$Z$ & \\
$\begin{array}{l}\text { Asymp. Sig. (2- } \\
\text { tailed) }\end{array}$ & .3 .196 \\
\hline
\end{tabular}

a. Grouping Variable: Kelas

pengetahuan awal tinggi dan belajar dengan menggunakan model GI yaitu skor rata-rata 1246.3750, standar deviasi 1.06066. Nilai maksimum untuk kelas GI yaitu 48 dan nilai minimum 45 dengan median 46,00.

Skor rata-rata hasil kemampuan kemampuan membaca pemahaman kelompok siswa yang memiliki pengetahuan awal rendah dan belajar dengan menggunakan model TGT yaitu 41.3750 dan standar deviasi 1.76777. Nilai maksimum kelompok siswa yang memiliki pengetahuan awal rendah dan belajar dengan menggunakan model TGT yaitu 44,00 dan nilai minimum 40,00 dengan median 41,50. Skor rata-rata tersebut lebih tinggi dibandingkan dengan kelompok siswa yang memiliki pengetahuan awal rendah dan belajar dengan menggunakan model GI yaitu skor rata-rata 30.6250 dan standar deviasi 1.18773. Nilai maksimum untuk kelompok siswa yang memiliki pengetahuan awal rendah dan belajar dengan menggunakan model GI yaitu 33,00 dan nilai minimum 30,00 dengan median 30,00.

Hipotesis pertama yang diajukan dalam peneltian ini menunjukan bahwa $\mathrm{H}_{0}$ ditolak karena berdasarkan hasil uji non parametric dengan menggunakan uji mann-whitney menunjukan bahwa nilai hasil uji $\mathrm{Z}$ yaitu $-3,196$ dan nilai signifikansi yaitu $0,001<0,05$. berikut merupakan tabel hasil uji non parametric.

Tabel 2

Deskripsi Data Perbedaan Kemampuan Kemampuan membaca pemahaman Berdasarkan Kelas Pembelajaran

Berdasarkan tabel 2 hasil uji non parametrik tersebut dapat disimpulkan bahwa adanya perbedaan hasil kemampuan kemampuan membaca pemahaman berdasarkan kelas pembelajaran. Guna melihat lebih jelas mengenai perbedaan hasil kemampuan kemampuan membaca pemahaman berdasarkan kelas pembelajaran dapat dilihat dari skor rata-rata hasil kemampuan kemampuan membaca pemahaman pada masing-masing kelas pembelajaran. Skor rata-rata hasil kemampuan kemampuan membaca pemahaman siswa yang pembelajarannya menggunakan model TGT yaitu 44.9333 sedangkan skor ratarata hasil kemampuan kemampuan membaca pemahaman siswa yang pembelajarannya menggunakan model GI yaitu 38.500. Berikut merupakan diagram nilai rata-rata hasil kemampuan kemampuan membaca pemahaman berdasarkan kelas pembelajaran:

\section{Gambar 1}

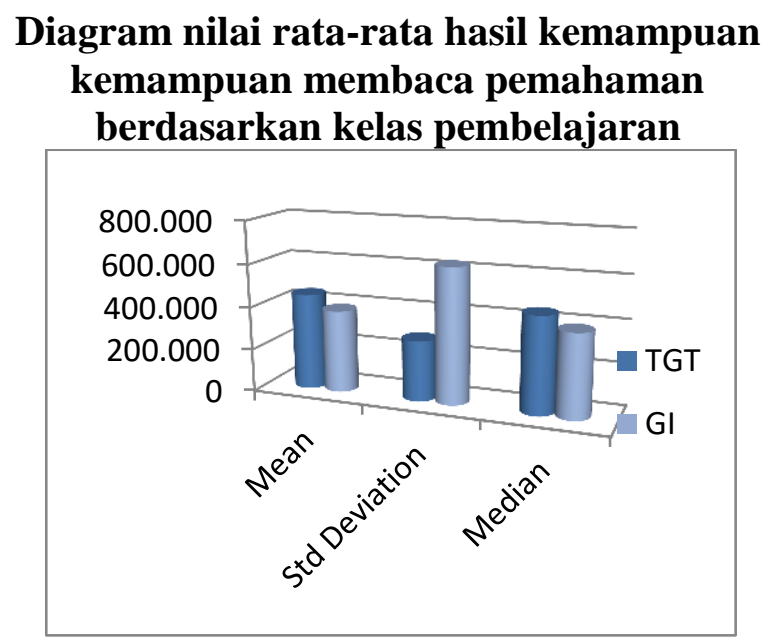

Jika dilihat berdasarkan skor rata-rata hasil kemampuan kemampuan membaca pemahaman berdasarkan kelas pembelajaran, dapat disimpulkan bahwa 
hasil kemampuan kemampuan membaca pemahaman siswa yang belajar dengan menggunakan model TGT lebih baik dari pada siswa yang belajar dengan menggunakan model GI.

Hipotesis ketiga dan keempat dengan tujuan melihat perbedaan hasil kemampuan kemampuan membaca pemahaman berdasarkan pengetahuan awal dan kelas pembelajaran. Guna menjawab hipotesis kedua dan ketiga dapat dianalisis menggunakan uji ANAVA dengan melakukan uji kruskall wallis guna melihat perbedaan hasil kemampuan kemampuan membaca pemahaman berdasarkan kelompok. Berikut tabel hasil uji kruskall walli

\section{Tabel 3}

Dekripsi Data Hasil Uji Kruskal Wallis

\begin{tabular}{|c|c|c|c|c|c|c|}
\hline \multirow[b]{2}{*}{$\begin{array}{l}\text { (I) } \\
\text { Grup }\end{array}$} & \multirow[b]{2}{*}{$\begin{array}{l}\text { (J) } \\
\text { Grup }\end{array}$} & \multirow[b]{2}{*}{$\begin{array}{l}\text { Mean } \\
\text { Difference } \\
\text { (I-J) }\end{array}$} & \multirow[b]{2}{*}{ Std. Error } & \multirow[b]{2}{*}{ Sig. } & \multicolumn{2}{|c|}{$\begin{array}{l}95 \% \text { Confidence } \\
\text { Interval }\end{array}$} \\
\hline & & & & & $\begin{array}{l}\text { Lower } \\
\text { Bound }\end{array}$ & $\begin{array}{l}\text { Upper } \\
\text { Bound }\end{array}$ \\
\hline \multirow[t]{3}{*}{$\begin{array}{l}\text { TGT } \\
\text { Tinggi }\end{array}$} & $\begin{array}{l}\text { TGT } \\
\text { Rendah }\end{array}$ & $8.000^{*}$ & .63738 & 000 & 6.2598 & 9.7402 \\
\hline & $\begin{array}{l}\text { GI } \\
\text { Tinggi }\end{array}$ & $3.0000^{*}$ & 63738 & .000 & 1.2598 & 4.7402 \\
\hline & $\begin{array}{l}\text { GI } \\
\text { Rendah }\end{array}$ & $18.7500^{*}$ & .63738 & 000 & 17.0098 & $\begin{array}{l}20.490 \\
2\end{array}$ \\
\hline \multirow{3}{*}{$\begin{array}{l}\text { TGT } \\
\text { Renda } \\
\text { h }\end{array}$} & $\begin{array}{l}\text { TGT } \\
\text { Tinggi }\end{array}$ & $-8.0000^{*}$ & .63738 & .000 & -9.7402 & -6.2598 \\
\hline & $\begin{array}{l}\text { GI } \\
\text { Tinggi }\end{array}$ & $5.0000^{*}$ & .63738 & .000 & -6.7402 & -3.2598 \\
\hline & $\begin{array}{l}\text { GI } \\
\text { Rendah }\end{array}$ & 10.7500 & 63738 & .000 & 9.0098 & $\begin{array}{l}12.490 \\
2\end{array}$ \\
\hline \multirow[t]{3}{*}{$\begin{array}{l}\text { GI } \\
\text { Tinggi }\end{array}$} & $\begin{array}{l}\text { TGT } \\
\text { Tinggi }\end{array}$ & $-3.0000^{*}$ & .63738 & .000 & 4.7402 & -1.2598 \\
\hline & $\begin{array}{l}\text { TGT } \\
\text { Rendah }\end{array}$ & $5.0000^{*}$ & .63738 & 000 & 3.2598 & 6.7402 \\
\hline & $\begin{array}{l}\text { GI } \\
\text { Rendah }\end{array}$ & $15.7500^{*}$ & .63738 & 000 & 14.0098 & $\begin{array}{l}17.490 \\
2\end{array}$ \\
\hline \multirow[t]{3}{*}{$\begin{array}{l}\text { GI } \\
\text { Renda } \\
\text { h }\end{array}$} & $\begin{array}{l}\text { TGT } \\
\text { Tinggi }\end{array}$ & $18.7500^{*}$ & .63738 & 000 & 20.4902 & $\begin{array}{l}- \\
17.009 \\
8\end{array}$ \\
\hline & $\begin{array}{l}\text { TGT } \\
\text { Rendah }\end{array}$ & $-10.7500^{*}$ & .63738 & .000 & 12.4902 & -9.0098 \\
\hline & GI Tinggi & $-15.7500^{*}$ & .63738 & 000 & $17.4902^{-}$ & $\begin{array}{l}- \\
14.009 \\
8\end{array}$ \\
\hline
\end{tabular}

Berdasarkan tabel 3 menunjukan adanya perbedaan yang sangat signifikan kemampuan kemampuan membaca pemahaman berdasarkan kelompok pengetahuan awal. Selain dengan menggunakan uji kruskall wallis, guna melihat perbedaan kemampuan kemampuan membaca pemahaman berdasarkan kelas pembelajaran dan pengetahuan awal berikut merupakan deskripsi uji tuckey mengenai perbedaan kemampuan kemampuan membaca pemahaman berdasarkan kelas pembelajaran dan kemampuan membaca pemahaman:

Tabel 4 Rekapitulasi Uji Tuckey

\begin{tabular}{|l|r|}
\hline & $\begin{array}{c}\text { kemampuan_membaca_ } \\
\text { pemahaman }\end{array}$ \\
\hline Chi- & 10.213 \\
Square & 1 \\
\hline Df & .001 \\
\hline Asymp. & \\
Sig. & \\
\hline
\end{tabular}

Berdasarkan tabel 4 hasil uji tuckey untuk menjawab hipotesis kedua dan ketiga menunjukan adanya perbedaan hasil kemampuan kemampuan membaca pemahaman berdasarkan kelompok (grup) pengetahuan awal dan kelas pembelajaran, dapat disimpulkan bahwa hasil kemampuan kemampuan membaca pemahaman kelompok siswa yang memiliki pengetahuan awal tinggi maupun rendah dan pembelajarannya menggunakan model TGT lebih baik dari pada model GI.

Hipotesis kedua yaitu melihat interaksi antara model pembelajaran dan pengetahuan awal terhadap kemampuan membaca pemahaman. Tabel hasil analisis statistik mengenai pengaruh interaksi sebagai berikut: 
Tabel 5

Deskripsi data uji interaksi pangaruh model pembelajaran dan pengetahuan awal terhadap kemampuan membaca pemahaman

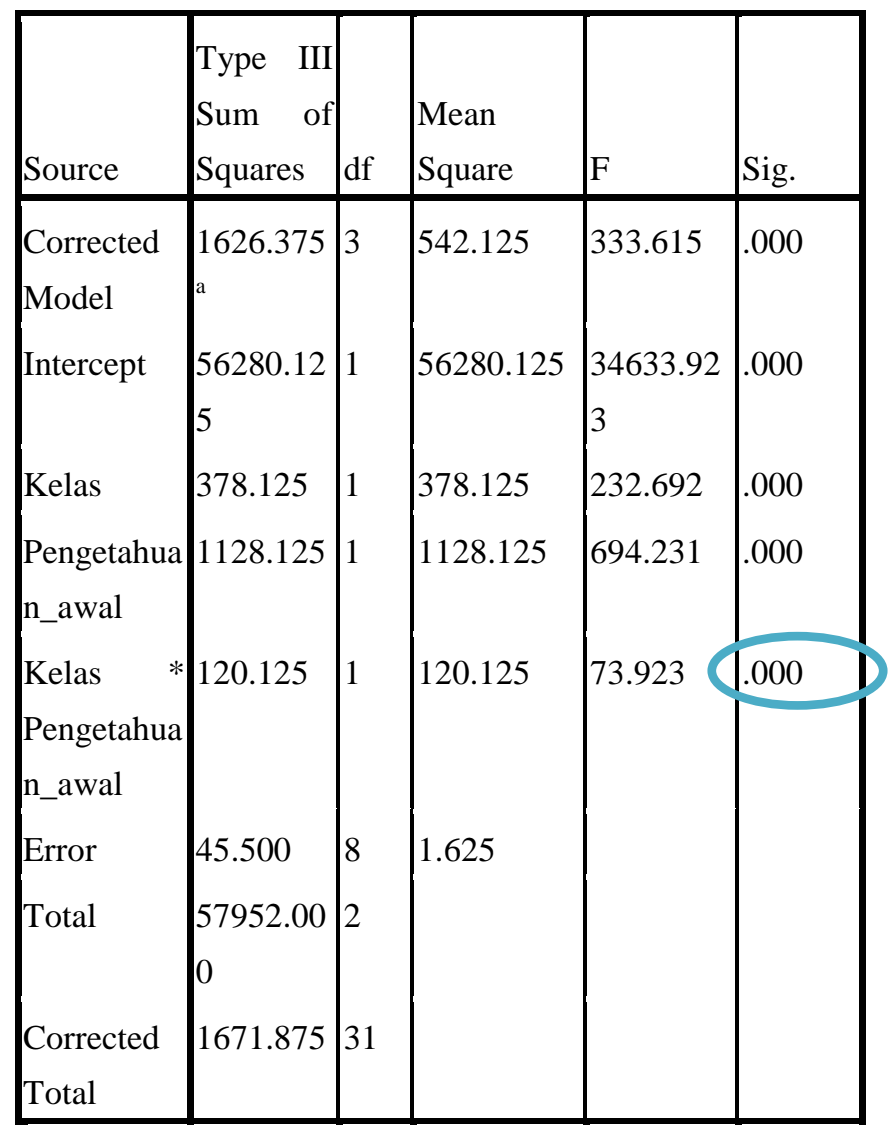

a. $\quad$ R Squared $=, 973$ (Adjusted R Squared $=, 970$ )

Berdasarkan tabel 5 Nilai signifikansi pada pengaruh interaksi antara model pembelajaran dan pengetahuan awal terhadap hasil kemampuan kemampuan membaca pemahaman memiliki nilai 0,000 yaitu $<0,05$ dengan demikian dapat disimpulkan bahwa hasil kemampuan kemampuan membaca pemahaman dipengaruhi sangat signifikan oleh model pembelajaran dan pengetahuan awal.

Berdasarkan tabel perhitungan uji statistik yang dibahas sebelumnya bahwa dapat disimpulkan hasil kemampuan kemampuan membaca pemahaman siswa yang pembelajarannya dengan menggunakan model TGT lebih baik dibandingkan dengan siswa yang pembelajarannya dengan menggunakan model GI. Hal itu sesuai dengan karakteristik TGT, Hosnan (2014:302) mengemukakan bahwa TGT memilik tahapan diantaranya 1) mengorientasikan peserta didik terhadap masalah, 2) mengorganisasi peserta didik untuk belajar, 3) membimbing penyelidikan individual maupun kelompok, 4) mengembangkan dan menyajikan hasil karya, 5) menganilisis dan mengevaluasi proses proses pemcahan masalah.

Pengetahuan awal menurut Abidin (2012a: 182) merupakan kemampuan latar belakang pengetahuan dan pengalaman yang telah dimiliki siswa tentang informasi atau konsep tentang sesuatu. Pengetahuan awal (Skemata) menggambarkan sekelompok konsep yang tersusun dalam diri seseorang yang dihubungkan dengan objek, tempat-tempat, tindakan atau peristiwa. Pengetahuan awal yang dimiliki seseorang akan sangat menentukan penguasaan konsep materi dan sangat mempengaruhi tingkat pemahaman membaca.

Hasil penelitian menunjukan bahwa terdapat interkasi antara model pembelajaran dengan pengetahuan awal terhadap kemampuan membaca pemahaman. Hal tersebut menunjukan bahwa model pembelajaran memiliki kontribusi terhadap kemampuan membaca pemahaman, begitupun hal nya dengan pengetahuan awaljuga memiliki kontribusi terhadap kemampuan membaca pemahaman. Jika dilihat secara statistik artinya kedua variabel tersebut memiliki pengaruh terhadap kemampuan membaca pemahaman. 


\section{Simpulan dan Saran}

Berdasarkan hasil analisa yang telah dilakukan, diperoleh bahwa: pertama, hasil kemampuan membaca pemahaman siswa yang menggunakan model Team Games Turnamen lebih tinggi dari pada siswa yang menggunakan model Grup Investigation. Kedua, hasil kemampuan membaca pemahaman kelompok siswa yang pengetahuan awal tinggi dan belajar dengan model Team Games Turnamen lebih tinggi dari pada kelompok siswa yang pengetahuan awal yang belajar dengan model Grup Investigation. Ketiga, hasil kemampuan membaca pemahaman kelompok siswa yang pengetahuan awal rendah dan belajar dengan model Team Games Turnamen lebih tinggi dari pada kelompok siswa yang pengetahuan awal rendah yang belajar dengan model Grup Investigation. Keempat, terdapat pengaruh interaksi anatara model pembelajaran dengan pengetahuan awal terhadap kemampuan membaca pemahaman.

Adapun saran dari hasil penelitian ini sebagai berikut:

1. Bagi sekolah, hendaknya memfasilitasi pembelajaran dengan menggunakan model Team Games Turnamen. Hal ini dikarenakan model Team Games Turnamen dapat meningkatkan kemampuan membaca pemahamansiswa.

2. Guru hendaknya mampu membangkitkan pengetahuan awal siswa melalui pendekatanpendekatan pembelajaran yang mampu meningkatkan aktivitas siswa.

3. Melalui penelitian ini, model Team Games Turnamen dapat dijadikan sebagai alternatif dalam pembelajaran di sekolah dasar khususnya mengenai kemampuan membaca pemahaman.

4. Pada peneliti selanjutnya diharapkan meneliti pada aspek keterampilan bahasa yang lainnya di luar keterampilan membaca pemahaman.

\section{DAFTAR PUSTAKA}

Abidin, Y.(2013). Pengembangan Model Penilaian Otentik dalam Pembelajaran Membaca Pemahaman di Sekolah Dasar. Disertasi. (Tidak diterbitkan), Bandung: UPI.

Abidin, Y.( 2012a). "Desain Sistem Pembelajaran Dalam Konteks Kurikulum 2013. Bandung: Refika Aditama.

Abidin, Y.(2012b). Pembelajaran Bahasa Berbasis Pendidikan Karakter. Bandung: Refika Aditama.

Andayani.(2009). Bahasa Indonesia. Panitia Sertifikasi Guru Rayon 13 FKIP UNS Surakarta. Surakarta: Mata Padi Presindo.

Arends, R. I. (2007). Learning to Teach. New York: McGraw Hill

Cline, F., Johnstone, C., \& King, T. (2006) Focus Group Reaction to Three Definition of Reading (as Originally Developed in Support NARAP Goal 1). Minneapolis, M.N.: National Accessible Reading Assesment Project.

Fanany, Burhan El.(2012). Teknik Baca Cepat Trik Efektif: Membaca 2 detik 1 Halaman. Yogyakarta: Araska.

OECD.(2013). Literacy Skills for Tomorrow: Futher Results From PISA 2000. Canada: OECD.

Hosnan.(2014). Pendekatan Saintifik Dan Kontekstual Dalam Pembelajaran Abad 21 Kunci Suskes Implementasi Kurikulum 2013. Bogor: Ghalia Indonesia. 
Ibrahim, Muhsin dkk. (2000). Pembelajaran Kooperatif. Surabaya: University Press.

Somadayo, Samsu.(2011). Strategi dan Teknik Pembelajaran membaca. Yogyakarta: Graha Ilmu.

Slavin, Robert E.(2005). Cooperative Learning: theory, research and practice, London: Allymand Bacon.

Tarigan, H. G.(2008). Membaca Sebagai Suatu Keterampilan Berbahasa. Bandung: Angkasa.

Trianto. (2011) Model Pembelajaran Terpadu Konsep,Strategi Dan Implementasinya. Jakarta: CV Pustaka Cendekia Utama

Westwood, Peter. (2008) What Teachers Need to Know about Reading and writing Difficulties, FirstEdition, Australia: Acer Press.

Winataputra, Udin, S. (2001). Modelmodel Pembelajaran Inovatif. Jakarta Pusat: Direktorat Jenderal Pendidikan Tinggi Departemen Pendidikan 